\title{
ETHANOL FRACTIONATION OF PLASMA AND ELECTROPHORETIC IDENTIFICATION OF INSULIN-BINDING ANTIBODY
}

\author{
By SOLOMON A. BERSON AND ROSALYN S. YALOW \\ (From the Radioisotope Service, Veterans Administration Hospital, Bronx 68, N. Y.)
}

(Submitted for publication October 10, 1956; accepted January 10, 1957)

In previous communications $(1,2)$ the presence of an insulin-binding globulin in the serum of insulin-treated patients was demonstrated, in vitro, by paper and starch electrophoresis and by ultracentrifugal fractionation employing insulin- $\mathrm{I}^{131}$ as a tracer. These findings were correlated with a slower disappearance of insulin- $\mathrm{I}^{131}$ from the blood stream of insulin-treated subjects than of control subjects. Insulin-binding globulin could be demonstrated only in insulin-treated subjects (diabetic or non-diabetic) but not in subjects who had never received insulin (control subjects). It appeared within four and one-half months after institution of insulin therapy in a newly treated subject under observation. It was concluded therefore that insulin-binding globulin satisfied the criteria for antibody $(1,2)$. The insulin-antibody complex appeared to migrate with the fast moving $\gamma$ globulins or just in advance of the $\gamma$ globulins on starch block and paper electrophoresis $(1,2)$ and preliminary experiments with ethanol fractionation of the serum suggested further that the antibody might reside in the $\beta$ rather than in the $\gamma$ globulin fraction (2). However, Weiger and Colwell (3) and Peters, Burrows, and Lowell (4) have since reported that, on paper electrophoresis, insulin- $\mathrm{I}^{131}$ migrates with the $\gamma$ globulins in the sera of insulin-resistant patients. In view of the reports of others that insulin-neutralizing activity present in the sera of insulin-resistant patients is restricted to the $\gamma$ globulin fraction (5-7) and that an anti-insulin factor present in the sera of patients with diabetic acidosis is associated with the $\alpha$ and $\beta$ globulins (8), further studies seemed indicated.

\section{METHODS}

Nine insulin-treated diabetic patients at the Bronx Veterans Administration Hospital served as subjects for this study. They had been under insulin therapy for at least four months and were in good control. None had ever experienced "insulin resistance." ACD plasma or serum obtained at least 24 hours after the last dose of insulin from each of these patients was fractionated with cold ethanol according to the methods of Lever and associates (9) into the following 3 fractions: II, I + III, IV - VI. Table I summarizes the distribution of electrophoretic components in the various fractions according to these authors (9). Since fraction VI contains only 2.2 per cent of the total plasma proteins, further separation of fraction IV - VI into fraction IV $+\mathrm{V}$ and fraction VI was not undertaken. In some cases where ACD plasma rather than serum was used, fibrinogen was partly precipitated from fraction I + III during prolonged dialysis and was removed subsequently. There was never any significant precipitation of insulin- $\mathrm{I}^{131}$. In some cases all fractions were concentrated to a volume of

TABLE I

Distribution of total protein and electrophoretic components in plasma protein fractions [from Lever and associates (9)]

\begin{tabular}{|c|c|c|c|c|}
\hline $\begin{array}{l}\% \text { Total plasma } \\
\text { proteins }\end{array}$ & $\begin{array}{l}\text { Fraction II } \\
10.8\end{array}$ & $\mathrm{I}+\underset{22.0}{+\mathrm{III}}$ & $\mathrm{IV}_{65.6}+\mathrm{V}$ & $\begin{array}{l}\text { VI } \\
2.2\end{array}$ \\
\hline \multirow{7}{*}{$\begin{array}{l}\text { Albumin } \\
\alpha_{1} \\
\alpha_{2} \\
\beta_{1} \\
\beta_{2} \\
\text { Fibrinogen } \\
\gamma\end{array}$} & \multicolumn{3}{|c|}{$\%$ of fraction } & \\
\hline & 3.1 & 0.5 & \multirow{6}{*}{$\begin{array}{r}81.3 \\
7.8 \\
4.7 \\
5.5 \\
0.7\end{array}$} & \\
\hline & 0.1 & 3.5 & & \\
\hline & & 13.3 & & \\
\hline & & 49.4 & & \\
\hline & 3.8 & 26.5 & & \\
\hline & 93.0 & 6.8 & & \\
\hline Total & 100. & 100. & 100. & \\
\hline
\end{tabular}

$2 \mathrm{ml}$. by freeze drying and were then dialyzed against 0.25 per cent $\mathrm{NaCl}$ or $0.067 \mathrm{M}$ phosphate buffer, $\mathrm{pH}$ 7.4.

Insulin- $\mathrm{I}^{131}$ was added in equal amounts to whole serum or plasma prior to fractionation and/or to the various fractions after separation. The mixtures were incubated at $37^{\circ}$ for about 30 minutes and were then subjected to electrophoresis on paper. In the concentrations employed, unbound insulin- $\mathrm{I}^{131}$ is adsorbed to the paper at the site of application ("origin") $(10,1,2)$ but insulin- $\mathrm{I}^{131}$ which is bound to any of the proteins migrates away from the origin along with the binding protein.

The insulin- $\mathrm{I}^{131}$ employed in this investigation was prepared from crystalline beef insulin ${ }^{1}$ with a specific activity of 3 to $12 \mathrm{mc}$. ${ }^{131}$ per $\mathrm{mg}$. insulin and contained less than 1.0 iodine atom per $36,000 \mathrm{M} . \mathrm{W}$. insulin. The

$1 \mathrm{We}$ are indebted to Dr. O. K. Behrens and Dr. C. W. Pettinga of Eli Lilly Co. for a generous supply of crystalline regular insulin lot No. 535664. 


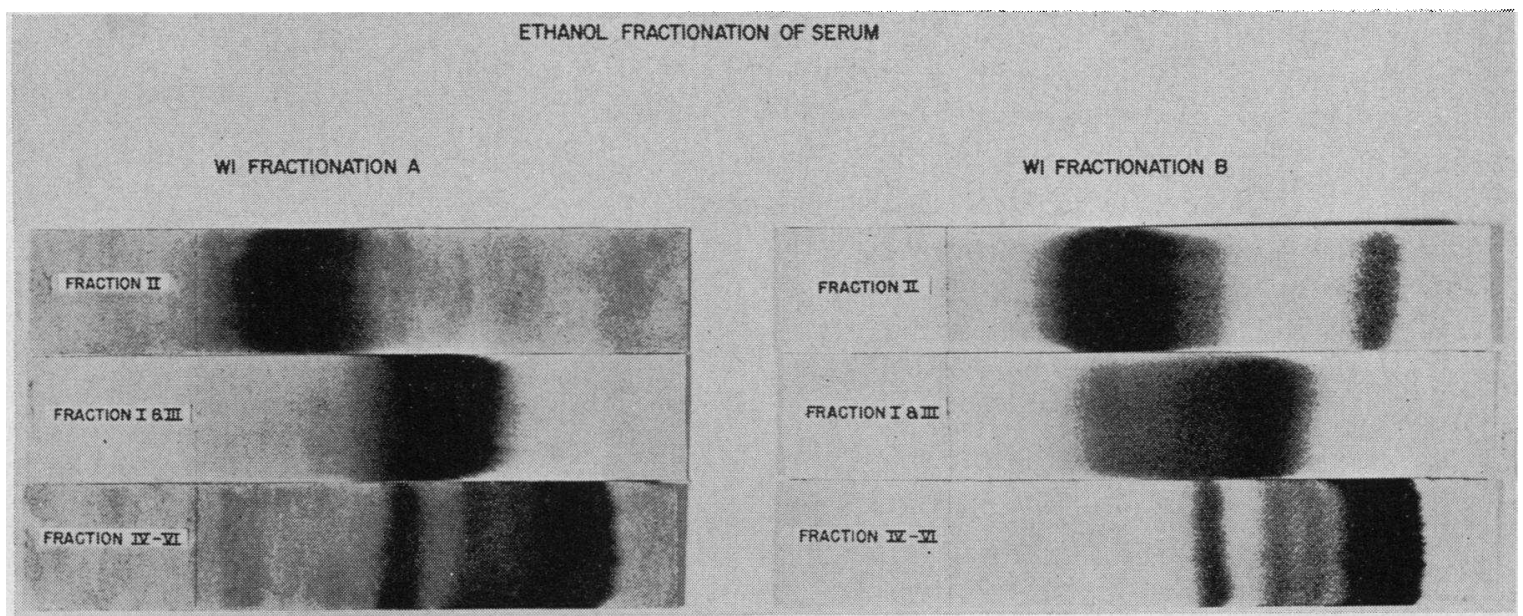

Fig. 1. Paper Electrophoresis of Protein Fractions Separated by Cold Ethanol According to Method of Lever AND Associates (9)

Two separate fractionations of same serum of subject $\mathrm{Wi}$.

method of preparation has been described previously (11). In order to protect against radiation damage (2, 12) at this high specific activity, the insulin was permitted to remain in contact with the iodinating solution for only about 5 minutes or less and was then dialyzed, with continuous mixing, for 45 to 60 minutes at $4^{\circ} \mathrm{C}$, against a large volume (2 liters) of distilled water. This usually removed about 90 per cent of the nonprotein bound $\mathrm{I}^{131}$. Serum albumin was then added to a final concentration of 50 to $100 \mathrm{mg}$. per $\mathrm{ml}$. to protect against further radiation damage (12) and dialysis was continued for another 7 to 18 hours until nonprotein bound $\mathrm{I}^{131}$ was less than 1 per cent of protein bound $\mathrm{I}^{131}$ as determined by analysis with paper electrophoresis. There was no iodination of the added serum albumin under these conditions. Since unprotected insulin was exposed to high concentrations of $\mathrm{I}^{\mathbf{1 3 1}}$ for less than an hour, the radiation damage incurred was minimal and did not exceed 3 to 5 per cent in any of the preparations.

\section{RESULTS}

Although a quantitative analysis was not performed, the protein fractions generally revealed, by inspection, essentially the same gross distribution of electrophoretic components on paper electrophoresis (Fractionation A, Figure 1) as anticipated from the quantitative analysis of Lever and associates (9). In some runs, however, the separations were not as clean, gamma globulin appearing in fraction I + III or $\beta$ globulins and albumin appearing in fraction II (Fractionation B, Figure 1).

The recovery of antibody in specific fractions, as evidenced by binding on paper electrophoresis, revealed certain consistencies among the antisera studied. With two exceptions (Table II, Fo, Fractionation $\mathrm{A}$ and $\mathrm{Ru}$ ) where a slight degree of binding was observed in fraction IV-VI, in addition to more marked binding in the other fractions, antibody in significant amounts was restricted to fraction I + III alone or to fraction I + III and fraction II. When antibody was present in both II and I + III, another fractionation on a sample of the same plasma revealed its presence only in fraction I + III in several cases (Table II). It was also observed that antibody was more likely to be recovered in fraction II when separation between II and I + III was incomplete, fraction II being contaminated with some of the $\beta$ globulins (e.g., Subject Wi, Figure 1, Table I). In all

TABLE II

Binding of insulin- $I^{131}$ to proteins in serum fractions separated with cold ethanol

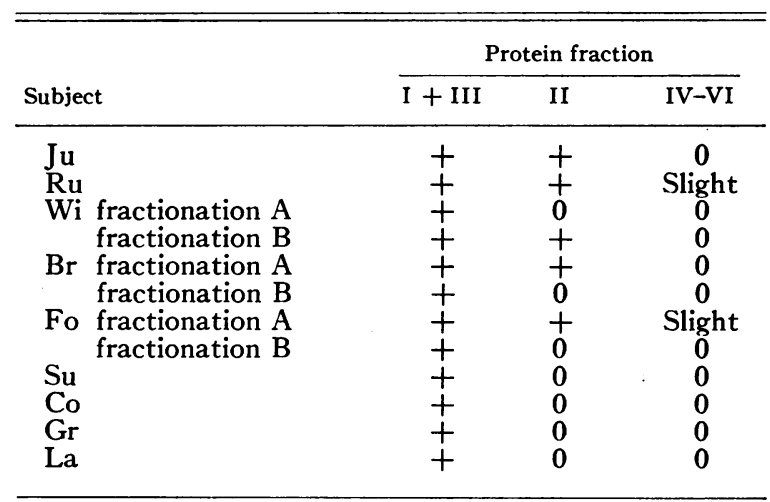


cases, regardless of the fraction in which antibody was recovered, the peak of bound insulin- $\mathrm{I}^{131} \mathrm{mi}$ grated between the $\gamma$ and $\beta$ globulins (Figure 2) or with the slowest moving $\beta$ globulins. This localization is well demonstrated in whole plasma or serum when the paper strips are scanned with a narrow window, employing a short resolving time of the circuit, so that the radioactivities are almost precisely juxtaposed to the corresponding stained proteins (Figure 3). Confirmation was readily obtained by section of the paper strips into thin segments which were assayed individually in a well scintillation counter; the peak of bound insulin activity corresponded with the relatively clear zone between $\beta$ and $\gamma$ globulins.

Whether insulin- $\mathrm{I}^{131}$ was added to whole plasma

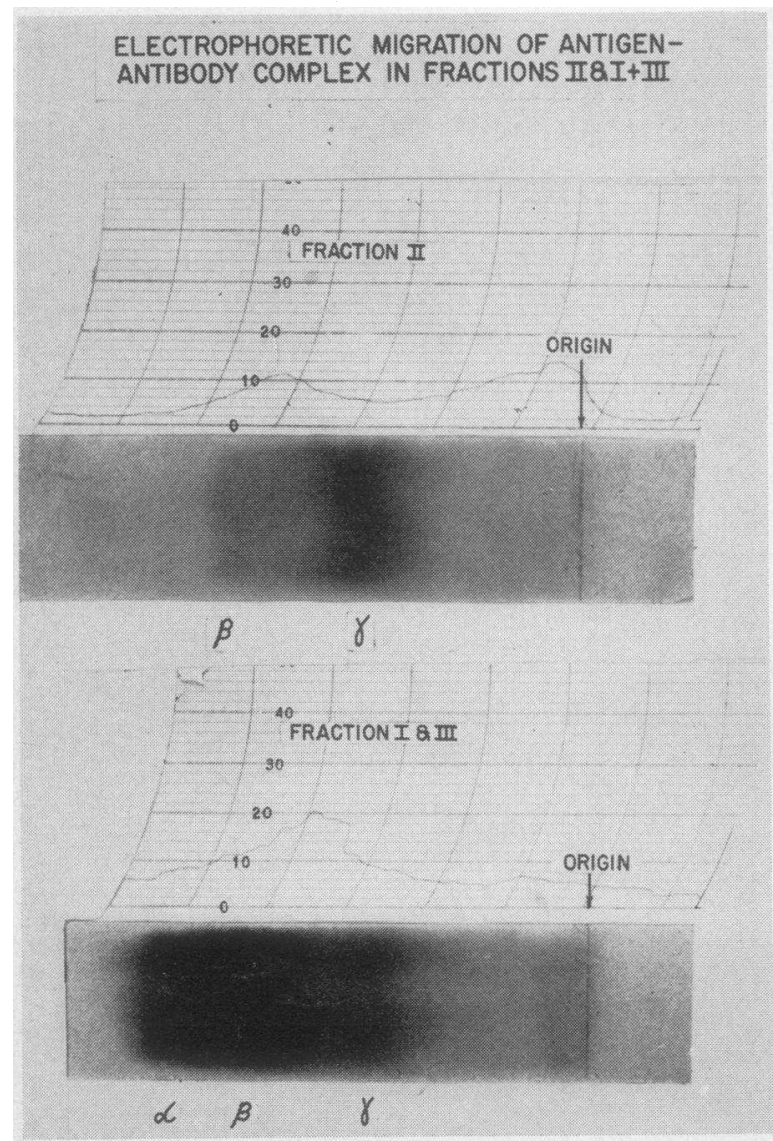

Fig. 2. Paper Radioelectrophoretograms of FracTIONS II AND I + III (Subject Ju) To Which InsuLIN-I ${ }^{131}$ WAS ADDED in vitro

The resolving time of the recording circuit was 10 seconds so that radioactivities are about $1 / 6$ of a vertical division to the left of the corresponding sites on the electrophoresis strips.

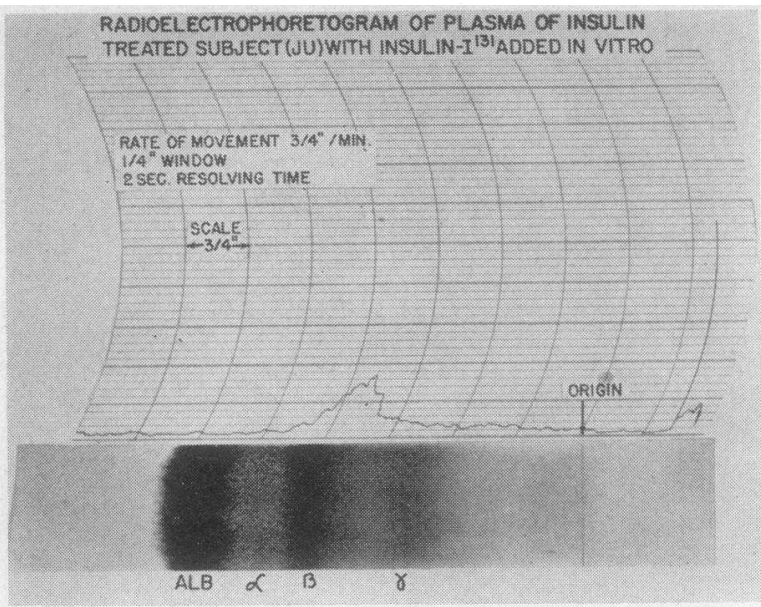

Fig. 3. Paper Radioelectrophoretogram of Plasma of Subject Ju to Which Insulin- ${ }^{131}$ Was Added in vitro

Resolving time of recording circuit short so that radioactivity curve corresponds almost precisely to subjacent sites on the electrophoresis strip.

or serum prior to fractionation or to the various fractions after separation was immaterial to the distribution of antibody among the fractions (Figure 4).

\section{DISCUSSION}

The present study indicates that insulin binding antibody has an electrophoretic mobility greater than that of the main mass of $\gamma$ globulins. In whole serum or in serum fractions, the insulin- $\mathrm{I}^{131}$-antibody complex migrated in the relatively clear zone between $\gamma$ and $\beta$ globulins. When plasma was employed, the peak of radioactivity generally corresponded to that of fibrinogen. However, the possibility that the uncomplexed insulin-binding antibody has a significantly different mobility and that its mobility is altered by binding to the insulin molecule must be considered. Since unbound insulin- $\mathrm{I}^{131}$ migrates in the region of $\alpha_{1}$ globulin when adsorption to the paper is prevented (2), it would be expected to influence the mobility of antibody after binding in the anodal direction if at all. Bound insulin- $\mathrm{I}^{131}$ always migrated either just in advance (towards the anode) of the stainable portion of fraction II or at the cathodal side of the proteins in fraction I + III. This position represents the line of separation between the proteins of the two fractions. Since, in the separated fractions, antibody was most frequently absent from fraction II, it gen- 


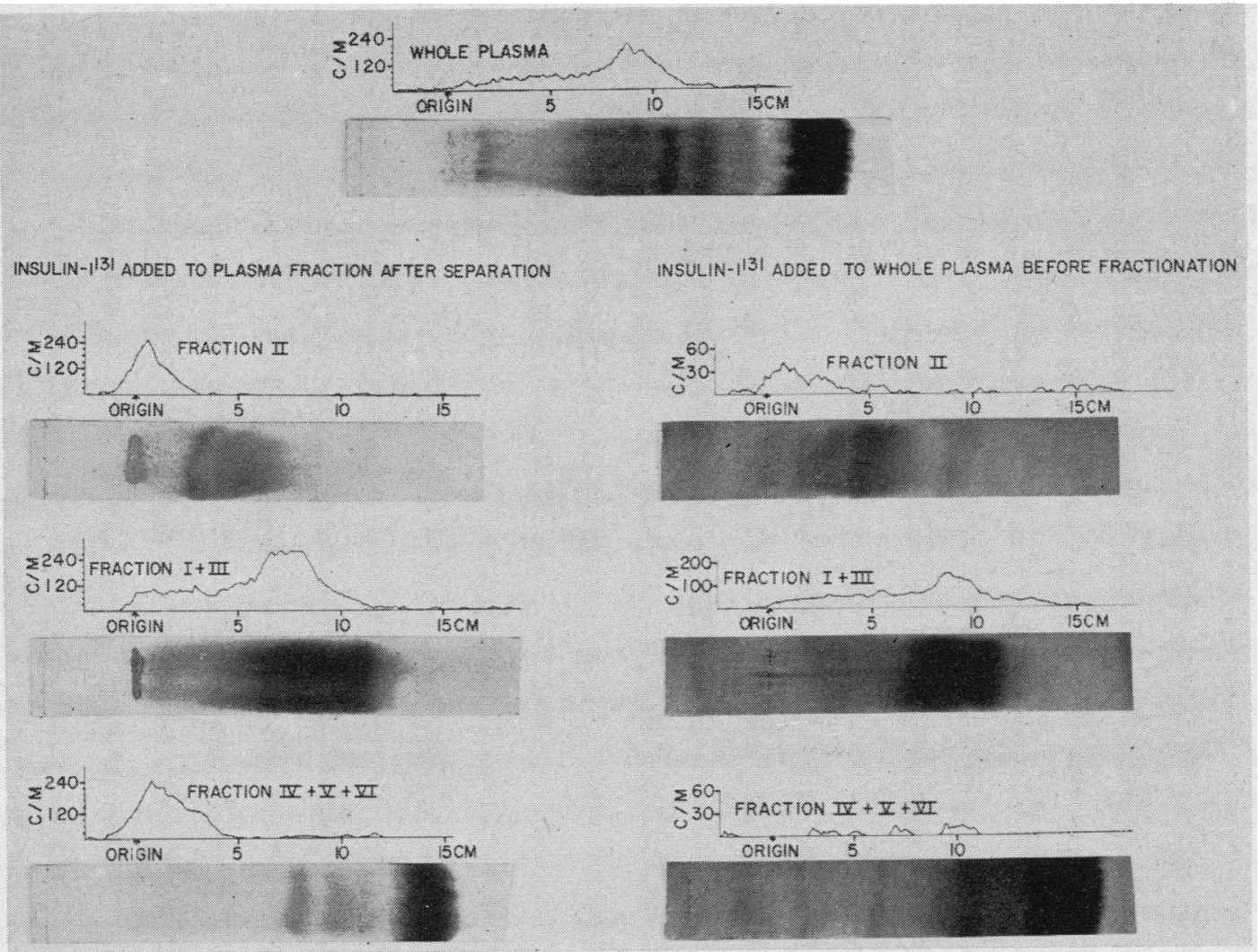

Fig. 4. Paper Radiolectrophoretograms of Plasma and Plasma Protein Fractions (Subject La) to Which Insulin-I ${ }^{131}$ Had Been Added in vitro Before and After Fractionation with Cold ETHANOL

erally did not have a mobility lower than that of the slowest migrating components of fraction I+ III. Since this is the zone of migration of the antibody-insulin complex, it may be inferred that binding of insulin did not affect significantly the electrophoretic mobility of insulin antibody. This observation also suggests that each antibody molecule may bind only a single insulin molecule or, at least, that the antigen-antibody complex does not contain a high ratio of insulin to antibody.

The presence of antibody in fraction II in some cases may be attributable to experimental variations in critical salt, alcohol and temperature conditions, since in these instances the fractions were not well delineated on electrophoresis and, on repeat fractionation of the same serum, antibody was frequently absent from fraction II. In any event, the insulin binding globulin migrates electrophoretically in the region of relatively low protein concentration between the $\gamma$ and $\beta$ globulins.

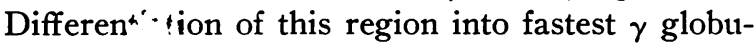

lins or slowest $\beta$ globulins would certainly be arbitrary but the constant presence of antibody in fraction I + III rather than in fraction II (where it is present only occasionally) favors its inclusion with the $\beta$ globulins. Perhaps the best compromise is the designation "inter $\gamma-\beta$ region" which is, in fact, the most accurate electrophoretic characterization.

Wasserman antibody (13) and horse antipneumococcus antibody (14) are also reported to have mobilities between those of the $\gamma$ and $\beta$ globulins. It is of further interest that Cann and Loveless (15) observed reagin activity of serum in patients sensitive to cottonseed or ragweed pollen to be most closely correlated with the $\beta$ globulin content of serum protein fractions separated by electrophoresis convection, although $\gamma_{1}$ globulin participation could not be directly excluded. More recently, Loveless and Cann (16) have examined, by similar methods, the serum of an insulin-resistant diabetic patient who exhibited some apparent in- 
sulin allergy as well, and found that while skin sensitizing antibody was associated with the $\beta$ globulins, blocking antibody was contained in fractions of lower mobility corresponding to the fastest and slowest $\gamma$ globulins or (in another specimen of the same subject) to all the $\gamma$ globulins. Their observations would indicate a definite heterogeneity in the electrophoretic characterization of the blocking antibody itself. Furthermore, because of its zone of localization, the blocking antibody would not appear to be identical with the insulin-binding antibody investigated in the present study, although the latter might, a priori, be suspected of possessing "blocking" activity. While it seems quite possible that a number of different antibodies to insulin are formed and that antibodies reported with different techniques are, in fact, different antibodies, it also appears reasonable to suggest that even the same antigenic stimulus may not always invoke the production of antibodies which have identical chemical compositions and electrophoretic mobilities in all subjects. In addition the possibility of distinct antibodies to pork and beef insulin should not be overlooked. In most studies mixtures of pork and beef insulin obtained from commercial sources were used in the demonstration of antibody. In the present study pure beef insulin was employed. A proper approach to the problem would appear to be the simultaneous testing of various protein fractions of the same serum for insulin-neutralizing, insulinbinding, insulin-blocking and skin sensitizing antibodies. The studies of Loveless and Cann (16) suggest that at least the last two of these activities definitely reside in different fractions. On the other hand, experiments reported elsewhere (17) indicate that the serum factor associated with the apparent inhibition of insulin degradation by liver homogenates is identical with the antibody responsible for the binding of insulin- $\mathrm{I}^{131}$ which has been demonstrated by zone electrophoresis. It would also seem possible that insulin-binding protein and insulin-neutralizing factors may be identical antibodies. However, a recent report by Field and Stetten ( 8 ) indicates the presence of an insulin-neutralizing factor (detected by the abolishment of the insulin effect on glycogen accumulation by rat diaphragm) in diabetic acidosis which is localized to the $\alpha$ and $\beta$ globulin fractions. It is clear that considerable work remains to be done before all these findings can be completely integrated.

\section{SUMMARY AND CONCLUSIONS}

1. The sera of nine insulin-treated subjects were fractionated with cold ethanol. The fractions were tested for the presence of insulin-binding antibody employing $I^{131}$ labeled crystalline beef insulin and paper strip electrophoresis. In all cases the antibody was present in fraction I + III ( $\beta$ and $\alpha$ globulins). In five cases antibody was also present in fraction II (mainly $\gamma$ globulin) but in three of these cases refractionation of the same serum revealed antibody to be present only in fraction I + III.

2. The zone of migration of the antibody-insulin complex was in the inter $\gamma-\beta$ region. The distribution of antibody among the fractions indicates that complexed and uncomplexed insulinbinding antibody have essentially the same mobility.

3. There was no difference, qualitatively, in the recovery of antibody in specific fractions when insulin- $\mathrm{I}^{131}$ was added to whole plasma or serum before or after fractionation.

\section{ACKNOWLEDGMENTS}

We wish to thank Mr. Manuel J. Villazon for the technical assistance in performing the ethanol fractionations. We also wish to thank Miss Eve Spelke and Mrs. Frieda Steiner for secretarial assistance. We are also indebted to the Dept. of Medical Illustration for the figures.

\section{Addendum}

Since this paper was submitted we have observed antibodies to pure pork insulin as well as to pure beef insulin in each of three antisera examined. In addition, marked cross reactions were observed.

\section{REFERENCES}

1. Berson, S. A., Yalow, R. S., Bauman, A., Rothschild, M. A., and Newerly, K., Persistence of I ${ }^{131}$-labeled insulin in the blood of insulin-treated subjects. (Abst.) Northwest Med., 1956, 55, 541.

2. Berson, S. A., Yalow, R. S., Bauman, A., Rothschild, M. A., and Newerly, K., Insulin- $\mathrm{I}^{121}$ metabolism in human subjects: Demonstration of insulin binding globulin in the circulation of insulin treated subjects. J. Clin. Invest., 1956, 35, 170.

3. Weiger, R .W., and Colwell, A. R., The inhibition of insulin action by serum gamma globulin. (Abst.) Clin. Research Proc., 1956, 4, 123. 
4. Peters, T., Burrows, B. A., and Lowell, F. C., Physical binding of insulin by gamma globulins from insulin-resistant subjects. (Abst.) Federation Proc., 1956, 15, 608.

5. De Filippis, V., and Iannaccone, A., Insulin-neutralising activity of gamma-globulins derived from the serum of an insulin-resistant patient. Lancet, 1952, 1, 1192.

6. Sehon, A. H., Kaye, M., McGarry, E., and Rose, B., Localization of an insulin-neutralizing factor by zone electrophoresis in a serum of an insulinresistant patient. J. Lab. \& Clin. Med., 1955, 45, 765.

7. Colwell, A. R., and Weiger, R. W., Inhibition of insulin action by serum gamma globulin. J. Lab. \& Clin. Med., 1956, 47, 844.

8. Field, J. B., and Stetten, D., Jr., Insulin antagonist activity of serum in diabetic acidosis. Federation Proc., 1956, 15, 250.

9. Lever, W. F., Gurd, F. R. N., Uroma, E., Brown, R. K., Barnes, B. A., Schmid, K., and Schultz, E. L., Chemical, clinical, and immunological studies on the products of human plasma fractionation. XL. Quantitative separation and determination of the protein components in small amounts of normal human plasma. J. Clin. Invest., 1951, 30, 99.

10. Kallee, E., and Seybold, G., Uber ${ }^{181} \mathrm{~J}$-signiertes Insulin III (Verteilung im Rattenorganismus). Ztschr. f. Naturforsch., 1954, 9B, 307.
11. Bauman, A., Rothschild, M. A., Yalow, R. S., and Berson, S. A., Distribution and metabolism of $\mathrm{I}^{12 \mathrm{t}}$ labeled human serum albumin in congestive heart failure with and without proteinuria. J. Clin. Invest., 1955, 34, 1359.

12. Yalow, R. S., and Berson, S. A., Effect of $x$-rays on trace-labeled $\mathrm{I}^{131}$-insulin and its relevance to biologic studies with I ${ }^{121}$-labeled proteins. Radiology, 1956, 66, 106.

13. Davis, B. D., Moore, D. H., Kabat, E. A., and Harris, A., Electrophoretic, ultracentrifugal and immuno-chemical studies on Wasserman antibody. J. Immunol., 1945, 50, 1.

14. Tiselius, A., and Kabat, E. A., An electrophoretic study of immune sera and purified antibody preparations. J. Exper. Med., 1939, 69, 119.

15. Cann, J. R., and Loveless, M. H., Distribution of sensitizing antibody in human serum proteins fractionated by electrophoresis-convection. J. Immunol., 1954, 72, 270.

16. Loveless, M. H., and Cann, J. R., Distribution of "blocking" antibody in human serum proteins fractionated by electrophoresis-convection. J. Immunol., 1955, 74, 329.

17. Yalow, R. S., and Berson, S. A., Apparent inhibition of liver insulinase activity by serum and serum fractions containing insulin-binding antibody. $J$. Clin. Invest., 1957, 36, 648. 